\title{
Pengelolaan Keuangan Desa Ditinjau Dari Undang- Undang Desa Menuju Masyarakat Yang Mandiri
}

\author{
Betha Rahmasari \\ Fakultas Hukum Universitas Islam Indonesia Yogyakarta Indonesia \\ Jln. Cik Di Tiro No. 1 Yogyakarta Indonesia \\ umdosen@gmail.com
}

\begin{abstract}
Abtract
The background of this research is the guarantee of recognition of the existence of the village through the formation of Law Number 6 of 2014 on Villages (Village Law). The Village Government has a strategic role and position in public services and empowerment of the community. Therefore, in order to empower the community and carry out service functions, the village must be empowered in any sector, one of which is the village financial management. This research will answer the formulation of the problem regarding what is the benchmark in the success of the village financial management in terms of village-related laws and regulations so that a prosperous and independent society is created? This is a normative juridical research with a statutory regulatory approach. The results of the study concluded that the affirmative policy of Law Number 6 of 2014 on Villages has a positive effect on the effectiveness of village governance. This is shown by the increase in the effectiveness of Village government organizations and the effectiveness of village deliberations. In terms of economic independence, efforts to strengthen village financing capacity can be seen from the widening of access to funding resources. The opportunity to empower the village can be made more possible through the empowerment of village-owned enterprises and village cooperation with other villages and / or cooperation with third parties.
\end{abstract}

Key Words: Independent; financial management; society

\begin{abstract}
Abstrak
Latar belakang penelitian adalah adanya jaminan pengakuan terhadap eksistensi desa melalui pembentukan Undang-Undang Nomor 6 Tahun 2014 tentang Desa (UU Desa). Pemerintah Desa memiliki peran dan posisi yang strategis dalam pelayanan publik dan pemberdayaan terhadap masyarakat. Oleh sebab itu, untuk dapat memberdayakan masyarakat dan menjalankan fungsi pelayanan, desa haruslah berdaya dan diberdayakan dalam sektor apapun salah satunya pengelolaan keuangan desa. Penelitian ini akan menjawab rumusan masalah mengenai apa yang menjadi tolak ukur dalam keberhasilan pengelolaan keuangan desa yang ditinjau dari peraturan perundang-undangan terkait desa sehingga tercipta masyarakat yang sejahtera dan mandiri? Jenis penelitian ini adalah penelitian yuridis normatif dengan pendekatan peraturan perundang-undangan. Hasil penelitian menyimpulkan kebijakan afirmatif undang-undang Nomor 6 Tahun 2014 tentang Desa berpengaruh positif terhadap efektivitas pemerintahan desa. Hal ini ditunjukkan oleh peningkatan efektivitas organisasi pemerintah Desa dan efektivitas deliberasi musyawarah desa. Dalam hal kemandirian ekonomi upaya penguatan kapasitas pembiayaan Desa terlihat dari semakin diperluasnya akses terhadap sumber daya pendanaan. Peluang memberdayakan Desa bisa lebih dimungkinkan melalui pemberdayaan badan usaha milik desa dan kerjasama desa dengan desa lain dan atau kerjasama dengan pihak ketiga.
\end{abstract}

Kata-kata Kunci: Pengelolaan keuangan; masyarakat; mandiri 


\section{Pendahuluan}

Desa dalam sistem ketatanegaraan Indonesia yang diatur dalam UndangUndang Dasar Negara Republik Indonesia Tahun 1945, sekaligus menunjukkan adanya hubungan antara Negara, desa, dan warga merupakan hal yang sangat mendasar dalam pembahasan undang-undang tentang desa. Sebagaian besar wilayah Indonesia terdiri atas pedesaan. Jika dibandingkan jumlah Kabupaten atau Kota dengan desa, jumlah desa lebih besar daripada kabupaten atau kota. Secara historis desa merupakan cikal bakal terbentuknya masyarakat politik dan pemerintahan di Indonesia jauh sebelum negara bangsa ini terbentuk. Struktur sosial di desa, masyarakat adat dan lain sebagainya telah menjadi institusi sosial yang mempunyai posisi yang sangat penting. Desa merupakan institusi yang otonom dengan taradisi, adat istiadat dan hukumnya sendiri serta relatif mandiri. Hal ini antara lain ditunjukkan dengan tingkat keragaman yang tinggi membuat desa mungkin merupakan wujud bangsa yang paling kongkret. ${ }^{1}$

Menurut Undang-Undang Nomor 6 Tahun 2014 tentang Desa, desa adalah kesatuan masyarakat hukum yang memiliki batas wilayah yang berwenang untuk mengatur dan mengurus urusan pemerintahan, kepentingan masyarakat setempat berdasarkan prakarsa masyarakat, hak asal usul, dan/atau hak tradisional yang diakui dan dihormati dalam sistem pemerintahan Negara Kesatuan Republik Indonesia. ${ }^{2}$ Desa, sejak kemerdekaan Republik ini sampai sekarang, hanyalah dipandang sebagai "bagian terkecil dari wilayah negara". Namun sejatinya desa adalah bagian vital yang tidak dapat dipisahkan dalam hierarkhi sturktur bernegara. Karena pada hakikatnya tidak akan ada suatu negara tanpa memiliki bagian-bagian terkecil yang dalam konteks negara Indonesia, biasa disebut dengan desa. Sebagaimana pendapat aristoteles ${ }^{3}$ yang mengatakan bahwa negara adalah persekutuan dari pada keluarga dan desa, guna memperoleh hidup yang sebaik-baiknya. Dengan logika bahwa negara itu diawali dari manusia, manusia itu kemudian membentuk keluarga, masingmasing keluarga kemudian membentuk kata negara (polis dalam bahasa Yunani), dengan tujuan untuk dapat mempertahankan diri dari serangan musuh. Sehingga dalam tafsir yang sama istilah republik dan istilah desa dapat diletakkan pada istilah negara atau dengan kata lain dapat pula diartikan bahwa desa adalah cikal bakal atau asal mula negara.

${ }^{1}$ HAW. Widjaja, Otonomi Desa, Raja Grafindo Indonesia, Jakarta, 2012, hlm. 4.

2 Pasal 1 angka 1 Undang-Undang Nomor 6 Tahun 2014 tentang Desa.

${ }^{3}$ Dikutip oleh Sri Soemantri Martosoewignjo, Sistem-Sistem Pemerintahan Negara-Negara ASEAN, Tarsito, Bandung, 1976, hlm. 3. 
Pemerintah desa sejatinya merupakan pemerintah yang paling dekat dengan masyarakat di tingkat yang paling bawah (level terendah dalam hierarkhi sistem ketatanegaraan Republik Indonesia). Sehingga, sekecil apapun pemerintah desa tetap memiliki peran dan posisi yang strategis dalam pelayanan publik dan pemberdayaan terhadap masyarakat. Oleh sebab itu untuk dapat memberdayakan masyarakat dan menjalankan fungsi pelayanan, desa haruslah berdaya dan diberdayakan dalam sektor apapun. Pemerintah di tingkat desa merupakan tatanan terkecil dari sebuah negara, baik buruknya pemerintah di tingkat pusat juga ditentukan mulai dari pemerintahan di tingkat desa. Pemahaman tentang pemerintahan desa yang utuh menjalankan fungsinya dengan lebih baik. Oleh sebab itu, persoalan pokok pemerintahan desa sebetulnya terkait tiga hal utama, yaitu politik desa, kewenangan desa dan anggaran desa. Ketiga persoalan tersebut terbingkai dalam satu isu utama, yaitu isu otonomi desa. ${ }^{4}$

Berdasarkan Peraturan Dalam Negeri Nomor 20 Tahun 2018 tentang Pengelolaan Keuangan Desa, disebutkan bahwa keuangan desa adalah semua hak dan kewajiban desa yang dapat dinilai dengan uang serta segala sesuatu berupa uang dan barang yang berhubungan dengan pelaksanaan hak dan kewajiban desa. Sedangkan pengelolaan keuangan adalah seluruh rangkaian kegiatan yang dimulai dari tahap perencanaan, pelaksanaan, penatausahaan, pelaporan hingga pertanggungjawaban yang dilaksanakan dalam satu tahun anggaran, terhitung mulai 1 Januari sampai dengan 31 Desember. Untuk menunjukkan hak dan kewajiban desa sangat terkait dengan struktur APB Desa, yang desa dan pembiayaan desa. Masing-masing komponen itu diuraikan lebih lanjut sebagai berikut: ${ }^{5}$

1. Pendapatan desa

Pendapatan desa, meliputi semua penerimaan uang melalui rekening desa yang merupakan hak desa dalam 1 tahun anggaran yang tidak perlu dibayar kembali oleh desa.

2. Belanja desa, meliputi semua pengeluaran dari rekeninf desa yang merupakan kewajiban desa dalam 1 tahun anggaran yang tidaj akan diperoleh pembayarannya kembali oleh desa. Belanja desa dipergunakan dalam rangka mendanai penyelenggaraan kewenangan desa.

3. Pembiayaan desa, meliputi semua penerimaan yang perlu dibayar kembali dan/atau pengeluaran yang akan diterima kembali baik pada tahun anggaran yang bersangkutan maupun pada tahun-tahun anggaran berikutnya.

${ }^{5}$ Umar Nain, Relasi Pemerintah Desa Dan Supradesa Dalam Perencanaan dan Penggaran Desa, Pustaka Pelajar, Yogyakarta, 2017, hlm. 227-231.
}

${ }^{4}$ Moh. Fadli, Jazim Hamidi, Mustafa Lutfi, Pembentukan Peraturan Desa Partisipatif (Head to A Good Village 
Pembangunan melalui partisipasi masyarakat desa merupakan salah satu upaya untuk memberdayakan potensi masyarakat desa dalam merencanakan pembangunan yang berkaitan dengan potensi sumber daya lokal berdasarkan pendekatan musyawarah, yaitu peningkatan aspirasi berupa keinginan dan kebutuhan nyata masyarakat, peningkatan motivasi dan peran serta kelompok masyarakat dalam proses pembanguna desa, dan peningkatan rasa memiliki pada kelompok masyarakat terhadap program kegiatan desa yang telah disusun.

\section{Rumusan Masalah}

Dari hasil uraian di atas, rumusan masalah yang akan diangkat yaitu mengenai apa yang menjadi tolak ukur dalam keberhasilan pengelolaan keuangan desa yang ditinjau dari undang-undang desa sehingga tercipta masyarakat yang sejahtera dan mandiri?

\section{Tujuan Penelitian}

Berdasarkan rumusan masalah sebelumnya, maka tujuan penelitian yang akan diraih adalah untuk mengetahui tolak ukur dalam keberhasilan pengelolaan keuangan desa yang ditinjau dari undang-undang desa sehingga tercipta masyarakat yang sejahtera dan mandiri.

\section{Metode Penelitian}

Jenis penelitian ini adalah penelitian yuridis normatif dengan pendekatan peraturan perundang-undangan.

\section{Hasil Penelitian dan Pembahasan}

Undang-Undang Nomor 6 Tahun 2014 tentang Desa hadir sebagai jalan baru bagi pembangunan harkat dan martabat desa. Banyaknya simpul regulasi, kebijakan, dan kultur yang harus diretasnya agar ia dapat tumbuh dan berkembang sesuai dengan cita-citanya, dengan adanya UU Desa, akan menjadi payung keragaman desa di Tanah air dengan segala kekhususannya. Lahirnya Undang-Undang Nomor 6 Tahun 2014 tentang Desa merupakan sebuah capaian besar dalam proses pembangunan di Indonesia dan menjadi harapan besar bagi masyarakat desa. Desa sebagai entitas yang mempunyaisifat dan ciri khas dapat membangun desanya dengan modal kekuatan dan peluang yang dimiliki. Amanat undang-undang tentang desa ini semakin kuat karena menjadi cita-cita 
mulia, yaitu membangun Indonesia dari pinggiran dengan memperkuat daerahdaerah dan desa dalam negara kesatuan.

Pengelolaan keuangan desa merupakan kegiatan yang meliputi perencanaan, pelaksanaan, penatausahaan, pelaporan, dan pertanggungjawaban keuangan desa, pengelolaan keuangan desa mencakup yaitu perencanaan (penyusunan) anggaran pendapatan dan belanja desa (APBDesa); pendapatan dan belanja; pengumpulan pendapatan (atau sering disebut ekstraksi) dari berbagai sumber: pendapatan asli desa, swadaaya masyarakat, bantuan dari pemerintahan atasan, dan lain-lain: pembelanjaan atau alokasi.

Keuangan desa sangat terkait dengan pemerintahan, kemasyarakatan dan pembangunan, untuk itu ada beberapa prinsip yang perlu diperhatikan. Pertama, pengelolaan keuangan bukan hanya menjadi kewenangan pemerintah desa, tetapi juga menjadi hak milik masyarakat, karena itu perlu partisipasi masyarakat dalam perencanaan Anggaran Pendapatan dan Belanja Desa (APBDesa), masyarakat perlu mengetahui secara transparan kondisi keuangan desa, dan pemerintah desa wajib bertanggungjawab mengelola keuangan. Kedua, dalam sektor pemerintahan, keuangan desa seyogyanya tidak semata dialokasikan untuk gaji pamong, tetapi bagaimana alokasi itu juga bisa mendorong peningkatan kemampuan sumber daya manusia (SDM) pamong desa. Ketiga, bidang-bidang kemasyarakatan juga perlu dijadikan sebagai bagian dari program desa dan perlu memperoleh dukungan dana yang cukup. Sebagai contoh adalah pembinaan muda-mudi dan juga penanganan kenakalan remaja.

Keuangan desa memiliki ruang lingkup pengelolaan yang tidak jauh berbeda dibandingkan pengelolaan keuangan pemerintahan pusat maupun pemerintahan daerah propinsi, kabupaten, dan kota. Dengan keterbatasan jumlah dana yang dikelola dan jumlah maupun kapasitas SDM yang mengelola keuangan desa, maka pengelolaan keuangan desa seyogyanya dibuat sederhana mungkin namun tidak mengorbankan azas transparansi dan akuntabilitas. Dalam pengelolaan dana desa, perlu juga mengidentifikasi adanya resiko terjadinya kesalahan baik bersifat administratif maupun substantif yang mengakibatkan terjadinya permasalahan hukum mengingat belum memadainya kompetensi kepala desa dan aparat desa dalam hal penatausahaan, pelaporan, dan pertanggungjawaban keuangan desa. Keberhasilan dari suatu pembangunan di desa tidak terlepas dari aspek pengelolaan keuangan desa yang di kelola dengan baik.

Sesuai makna yang terangkum dalam pengertian desa sebagai masyarakat hukum yang berhak mengatur dan mengurus kepentingannya sendiri, maka peran dan keterlibatan masyarakat dalam penyelenggaraan pemerintahan dan pembangunan desa menjadi keharusan. Karena, pada dasarnya desa adalah 
organisasi milik masyarakat. Tata kelola desa secara tegas juga mensyaratkan hal itu, terlihat dari fungsi pokok musyawarah desa sebagai forum pembahasan tertinggi di desa, pembahasan hal-hal yang strategis bagi keberadaan dan kepentingan desa. Dengan demikian, peran dan keterlibatan masyarakat juga menjadi keharusan dalam pengelolaan keuangan desa. Oleh sebab itu, setiap tahap kegiatan harus memberikan ruang bagi peran dan keterlibatan masyarakat. Masyarakat dimaksud secara longgar dapat dipahami sebagai warga desa setempat, 2 orang atau lebih, secara sendiri-sendiri maupun bersama, berperan dan terlibat secara positif dan memberikan sumbangsih dalam pengelolaan keuangan desa. Namun, bila itu dilakukan secara pribadi oleh orang seorang warga desa, tentu akan cukup merepotkan. Oleh karena itu, peran dan keterlibatan dimaksud hendaknya dilakukan oleh para warga desa secara terorganisasi melalui lembaga kemasyarakatan dan/atau lembaga masyarakat yang ada di desa setempat. Peran dan keterlibatan masyarakat menjadi faktor penting, karena: ${ }^{6}$

1) menumbuhkan rasa tanggungjawab masyarakat atas segala hal yang telah diputuskan dan dilaksanakan.

2) menumbuhkan rasa memiliki, sehingga masyarakat sadar dan sanggup untuk memelihara dan mengembangkan hasil-hasil pembangunan (swadaya), dan

3) memberikan legitimasi/keabsahan atas segala yang telah diputuskan.

Untuk mencapai efektivitas dan efisiensi dalam pengelolaan keuangan desa diperlukan sejumlah asas atau prinsip yang harus dujadikan pedoman. Asas atau prinsip-prinsip dimaksud adalah:

1. Asas kesatuan, yaitu asas atau prinsip yang menghendaki agar semua pendapatan dan belanja desa disajikan dalam kesatuan dokumen anggaran desa.

2. Asas universalitas, yaitu asas atau prinsip yang mengharuskan agar setiap transaksi keuangan desa ditampilakn secara utuh dalam dokumen anggaran desa.

3. Asas tahunan yaitu asas atau prinsip yang membatasi masa berlakunya anggaran untuk suatu tahun anggaran.

4. Asas spesialitas, yaitu asas atau prinsip yang mewajibkan agar setiap kredit anggaran yang disediakan terinci secara jelas peruntukannya.

5. Asas akuntabilitas yang berorientasi pada hasil yaitu asas atau prinsip yang menentukan bahwa setiap kegiatan pengelolaan keuangan desa harus dapat dipertanggungjawabkan kepada masyarakat desa, sesuai dengan ketentuan perundang-undangan.

${ }^{6}$ Ibid., hlm. 237-238. 
6. Asas proporsionalitas yaitu asas atau prinsip yang mengutamakan keseimbangan antara hak dan kewajiban dalam pengelolaan keuangan desa.

7. Asas profesionalitas yaitu asas atau prinsip yang mengutamakan berdasarkan kode etik dan ketentuan perundang-undangan yang berlaku.

8. Asas keterbukaan yaitu asas atau prinsip yang membuka diri terhadap hak masyarakat untuk memperoleh informasi yang benar, jujur dan tidak diskriminatif tentang pengelolaan keuangan desa dengan tetap memperhatikan perlindungan terhadap hak pribadi dan golongan.

9. Asas pemeriksaan keuangan oleh Badan Pemeriksa Keuangan (BPK) yang bebas dan mandiri, yaitu asas atau prinsip yang memberikan kebebasan bagi BPK untuk melakukan pemeriksaan keuangan desa dengan tidak boleh dipengaruhi oleh siapapun.

10. Asas value for money yaitu asas atau prinsip yang menekankan bahwa dalam pengelolaan keuangan desa harus dilakukan secara ekonomis, efisien, dan efektif.

11. Asas kejujuran yaitu asas atau prinsip yang menenkankan bahwa dalam pengelolaan dana publik (termasuk APBDes) harus dipercayakan kepada aparat yang memiliki intergritas dan kejujuran yang tinggi, sehingga potensi munculnya praktek korupsi, kolusi dan nepotisme dapat diminimalis.

12. Asas pengendalian yaitu asas atau prinsip yang menghendaki dilakukannya monitoring terhadap penerimaan maupun pengeluaran anggaran pendapatan dan belanja desa (APBDes) sehingga bila terjadi selisih (varians) dapat segera dicari penyebab timbulnya selisih tersebut.

13. Asas ketertiban dan ketaatan terhadap peraturan perundang-undangan yaitu asas atau prinsip yang mengharuskan bahwa dalam pengelolaan keuangan desa wajib berpedoman kepada peraturan perundangundangan yang berlaku.

14. Asas bertanggungjawab yaitu asas atau prinsip yang mewajibkan kepada penerima amanah atau penerima mandate untuk mempertanggungjawabkan pengelolaan dan pengendalian sumberdaya dan pelaksanaan kebijakan yang dipercayakan kepadanya dalam rangka pencapaian tujuan yang telah ditetapkan.

15. Asas keadilan yaitu asas atau prinsip yang menenkankan perlunya keseimbangan distribusi kewenangan dan pendanaannya dan atau keseimbangan distribusi hak dan kewajiban berdasarkan pertimbangan objektif.

16. Asas kepatutan yaitu asas atau prinsip yang menekankan adanya suatu sikap dan tindakan yang wajar dan proporsional.

17. Asas manfaat untuk masyarakat yaitu asas atau prinsip yang mengharuskan bahwa keuangan desa wajib digunaan atau diutamakan untuk memenuhi kebutuhan masyarakat desa.

Berbagai asas atau prinsip pengelolaan keuangan tersebut perlu dijadikan pedoman dalam mengelola keuangan desa, agar dana yangjumlahnya sangat terbatasitu dapat dipergunakan secara efektif, efisien, ekonomis dan berkeadilan. 
Secara efektif maksudnya bahwa pengelolaan keuangan desa tersebut harus dapat mencapai tujuan atau sasaran yang ingin dicapai, secara efisien, maksudnya bahwa pengelolaan keuangan dimaksud dapat menghasilkan perbandingan terbaik antara masukan dengan keluarannya. Sedangkan secara ekonomis, maksudnya bahwa pengelolaan keuangan tersebut dapat menghasilkan perbandingan terbaik anatara masukan dengan nilai masukan, adapun secara berkeadilan, maksudnya bahwa pengelolaan keuangan tersebut harus dapat memenuhi rasa keadilan dalam masyarakat. ${ }^{7}$

Keuangan desa adalah semua hak dan kewajiban dalam rangka penyelenggaraan pemerintahan desa yang dapat dinilai dari uang, termasuk di dalamnya segala bentuk kekayaan yang berhubungan dengan hak dan kewajiban desa tersebut. Keuangan desa berasal dari pendapatan asli desa, APBD, dan APBN. Penyelenggaraan urusan pemerintahan desa yang menjadi kewenangan desa didanani dari APBDes, bantuan pemerintahan pusat dan bantuan pemerintah daerah. Penyelenggaraan urusan pemerintahan daerah yang diselenggarakan oleh pemerintah desa didanai dari APBD, sedangkan penyelenggaraan urusan pemerintah pusat yang diselenggarakan oleh pemerintah desa didanai dari APBN. Sumber pendapatan desa berasal dari berikut ini: ${ }^{8}$

1. Pendapatan asli desa yang berasal dari hasil usaha desa, hasil kekayaan desa, hasil swadaya dan partisipasi, hasil gotongroyong, dan lain-lain pendapatan asli desa yang sah.

2. Bagi hasil pajak daerah kabupaten/kota paling sedikit 10\% (sepuluh per seratus) untuk desa dan dari retribusi kabupaten/kota yang sebagian diperuntukkan bagi desa.

3. Bagian dari dana perimbangan keuangan pusat dan daerah yang diterima kabupaten/kota untuk desa paling sedikit 10\% (sepuluh per seratus), yang dibagi ke setiap desa secara proporsional yang merupakan alokasi dana desa.

4. Bantuan keuangan dari pemerintah, pemerintah provinsi, dan pemerintah kabupaten/kota dalam rangka pelaksanaan urusan pemerintahan.

5. Hibah dan sumbangan dari pihak ketiga yang tidak mungkin.

Pemerintah desa wajib mengelola keuangan desa secara transparan, akuntabel, partisipasi serta dilakukan dengan tertib dan disiplin. Transparan artinya dikelola secara terbuka; dan partisipatif artinya melibatkan masyarakat dalam penyusunannya. Di samping itu, keuangan desa harus dibukukan dalam sistem pembukuan yang benar sesuai dengan kaidah sistem akuntasi keuangan

\footnotetext{
${ }^{7}$ Chabib Soleh dan Heru Rochmansjah, Pengelolaan Keuangan Desa, Fokus Media, Bandung, 2014, hlm. 7-8.

8 Pasal 72 ayat (1) Undang-undang Nomor 6 Tahun 2014 tentang Desa.
} 
pemerintahan. Sistem pengelolaan keuangan desa mengikuti sistem anggaran nasional dan daerah; yaitu mulai 1 Januari sampai dengan 31 Desember. Kepala Desa sebagai kepala pemerintah desa adalah pemegang kekuasaan pengelolaan keuangan desa dan mewakili pemerintah desa dalam kepemilikan kekayaan desa yang dipisahkan. Oleh karena itu, kepala desa mempunyai kewenangan.

1. Menetapkan kebijakan tentang pelaksanaan APBDes.

2. Menetapkan kebijakan tentang pengelolaan barang desa.

3. Menetapkan bendahara desa.

4. Menetapkan petugas yang melakukan pemungutan penerimaan desa.

5. Menetapkan petugas yang melakukan pengelolaan barang milik desa.

Kepala desa dalam melaksanakan pengelolaan keuangan desa dibantu oleh pelaksana tehnis pengelolaan keuangan desa (PTPKD), yaitu sekertaris desa dan perangkat desa lainnya. Sekertaris desa bertindak selaku koordinator pelaksanaan pengelolaan keuangan desa dan bertanggungjawab kepada kepala desa. Pemegang kas desa adalah bendahara desa. Kepala desa menetapkan bendahara desa dengan keputusan kepala desa.

Peraturan Menteri Desa, Pembangunan Daerah Tertinggal, Dan Transmigrasi Republik Indonesia Nomor 16 Tahun 2018 tentang Prioritas Penggunaan Dana Desa Tahun 2019, Pembangunan Desa dikelola secara partisipatif dikarenakan melibatkan peran serta masyarakat desa. Pembangunan desa mengarah pada terwujudnya kemandirian Desa dikarenakan kegiatan pembangunan desa wajib diswakelola oleh desa dengan mendayagunakan sumber daya manusia di desa serta sumber daya alam dan lingkungan secara berkelanjutan. Agar desa mampu menjalankan kewenangannya, termasuk mampu menswakelola pembangunan desa, maka desa berhak memiliki sumbersumber pendapatan. Dana desa yang bersumber dari APBN merupakan salah satu bagian dari pendapatan desa. Tujuan pemerintah menyalurkan dana desa secara langsung kepada desa adalah agar desa berdaya dalam menjalankan dan mengelola untuk mengatur dan mengurus prioritas bidang pembangunan dan pemberdayaan masyarakat desa.

Pembangunan melalui partisipasi masyarakat desa merupakan salah satu upaya untuk memberdayakan potensi masyarakat desa dalam merencanakan pembangunan yang berkaitan dengan potensi sumber daya lokal berdasarkan pendekatan masyarakat, yaitu meningkatkan aspirasi berupa keinginan dan kebutuhan nyata masyarakat, peningkatan motivasi dan peran serta kelompok masyarakat dalam proses pembangunan desa dan peningkatan rasa memiliki pada kelompok masyarakat terhadap program kegiatan desa yang telah disusun. 
Prinsip kerja dari pembangunan pedesaan melalui partisipasi masyarakat adalah sebagai berikut:

1. Program kerja disampaikan secara terbuka kepada masyarakat dengan melakukan komunikasi partisipatif agar mendapatkan dukungan masyarakat.

2. Program kerja dilaksanakan melalui kerjasama dan kerja bersama kelompok antar masyarakat, pejabat desa, dan segenap warga dalam rangka memperkecil hambatan dalam program.

3. Program kerja tidak mengarahkan pada golongan tertentu dalam masyarakat atau kelompok agar tidak menimbulkan perpecahan.

4. Selama program berjalan koordinasi dilakukan secara vertikal maupun horizontal.

5. Tidak perlu bersikap Superior atau merasa paling tahu dalam setiap kesempatan pelaksanaan program kerja.

6. Tidak perlu memberikan janji kepada siapapun Tetapi kesungguhan kerja dalam konteks program kerja yang sudah ditentukan.

Program pemberdayaan masyarakat desa dalam proses pembentukan Perda ditunjukkan untuk mewujudkan perdamaian yang aspiratif dilakukan dengan dasar bahwa setiap warga desa berhak menyampaikan pendapat, masukkan, saran, baik secara lisan maupun tertulis, untuk disampaikan dan dibahas dalam musyawarah desa titik warga bisa mengemukakan pendapat saran dan masukan melalui wakil-wakilnya, seperti tokoh adat tokoh agama, tokoh masyarakat, tokoh pendidikan, perwakilan kelompok tani nelayan, perajin, dan lain-lain.

Perencanaan pembangunan dapat dilihat berdasarkan unsur-unsur yang membentuknya, yakni perencanaan dan pembangunan titik perencanaan menurut lembaga administrasi negara merupakan upaya memilih prioritas dan/atau cara alternatif untuk mencapai tujuan, pengalokasian sumber daya yang bertujuan mencapai tujuan yang berkaitan dengan masa depan, serta kegiatan yang terus-menerus. ${ }^{9}$ Definisi ini sejalan dengan pendapat Conyers, bahwa perencanaan adalah proses yang terus-menerus melibatkan keputusan, alternatif atau pilihan, mengenai cara-cara alternatif penggunaan sumber daya dengan tujuan menghasilkan sasaran seperti spesifik untuk waktu yang akan datang. ${ }^{10}$ Untuk mendapatkan hasil perencanaan pembangunan desa yang baik, tepat waktu, tepat sasaran berdayaguna, dan berhasil guna, dibutuhkan terlibatan masyarakat dalam perencanaan pembangunan karena masyarakat sebagai salah satu unsur dalam pembangunan mengetahui sekaligus memahami apa yang ada

\footnotetext{
${ }_{9}$ Riyadi dan Bratakusumah, Perencanaan Pembangunan Daerah, Gramedia Pustaka Utama, Jakarta, 2004, hlm. 4.

${ }^{10}$ Conyers, Perencanaan Sosial Di Dunia Ketiga Suatu Pengantar, Gadjah Mada University Pers, Yogyakarta, 1991, hlm. 3 .
} 
di wilayahnya. Selain itu, dengan melibatkan masyarakat dalam proses perencanaan pembangunan pemerintah telah memberikan kepercayaan kepada masyarakatnya sehingga mereka dapat merasa ikut bertanggungjawab dan Merasa memiliki program-program pembangunan yang menguntungkan bagi pelaksanaan nya dapat disimpulkan bahwa perencanaan pembangunan adalah alat merencanakan sesuatu untuk masa yang akan datang untuk melakukan perubahan yang lebih baik dengan adanya keterlibatan masyarakat dalam pelaksanaan perencanaan tersebut.

Pembangunan harus menyangkut semua pihak yaitu dari tingkat pusat sampai tingkat daerah pembangunan pertama harus dibina dan dikembangkan adalah pembangunan desa berkenaan dengan pembangunan desa pembangunan desa diartikan sebagai berikut adalah proses perubahan yang terus-menerus dan berkesinambungan yang diselenggarakan oleh masyarakat beserta pemerintah untuk meningkatkan kesejahteraan lahir dan batin materi dan spiritual berdasarkan Pancasila yang berlangsung di desa. ${ }^{11}$

Langkah strategis proses belajar sosial dalam konteks ketahanan masyarakat desa adalah mempertemukan masyarakat dengan dunia nyatanya dalam kehidupan sehari-hari yang di bangun dan digerakkan berdasarkan aturan aturan hukum tentang desa. Proses belajar sosial ini akan menumbuhkan kesadaran otonom tentang aturan-aturan hukum yang berkaitan dengan desa sehingga partisipasi masyarakat dalam pengelolaan urusan desa menjadi autentik dan bukan sekedar produk mobilisasi partisipasi proyek-proyek pembangunan. Proses belajar sosial melalui pengembangan ketaatan pada aturan hukum negara secara bertahap membangun pondasi hukum positif dalam penyelenggaraan pemerintah desa pelaksanaan pembangunan desa pembinaan kemasyarakatan desa dan pemberdayaan masyarakat desa. ${ }^{12}$

Salah satu masalah kegagalan desa menggerakkan usaha ekonomi desa adalah aspek kepemimpinan desa kepala desa sebagai pimpinan desa tidak mempunyai imajinasi dalam raksasa yang kuat untuk menggerakkan masyarakat dan mengkonsolidasi Aset ekonomi lokal kepala desa ataupun Pemerintah Desa hanya disibukkan dengan mengelola bantuan dari pemerintah baik pusat provinsi maupun kabupaten kota dan bantuan yang diberikan tersebut sering belum menyentuh gerakan ekonomi lokal. Beberapa kasus matinya badan usaha milik desa terjadi saat pergantian kepala desa setelah diganti oleh Kepala Desa Baru, Badan Usaha Milik Desa Ledug, berhenti beraktifitas, dan akhirnya mati.

11 Taliziduhu Ndraha, Pembangunan Desa Dan Administrasi Pemerintahan Desa, Yayasan Karya Dharma, Jakarta, 1985, hlm. 71.

${ }_{12}$ M. Mustofa Ihsan, Ketahanan Masyarakat Desa, Kementerian Desa Pembangunan Daerah Tertinggal dan Transmigrasi Republik Indonesia, Jakarta, 2015, hlm. 29. 
Hal ini disebabkan adanya ketergantungan yang tinggi kepada kepala desa yang lama. Aspek kepemimpinan desa pada kenyataan menjadi salah satu faktor kunci kegagalan ataupun keberhasilan dalam menggerakkan potensi ekonomi lokal. Peran kepala desa sebagai pimpinan masyarakat harus memiliki kemampuan membangkitkan usaha ekonomi masyarakat berdasarkan potensi yang dimiliki oleh desa kepala desa mengambil prakarsa untuk mengembangkan ekonomi dengan membuat pelatihan-pelatihan secara mandiri serta melakukan revitalisasi aset desa hingga menghasilkan pendapatan asli desa yang sangat besar. Usaha ekonomi desa melalui keberadaan badan usaha milik desa layak untuk dikembangkan kembali titik tentunya dengan sejumlah perbaikan yang fundamental agar keberadaan badan usaha milik desa dapat menjadi tulang punggung perekonomian desa.

Pada era otonomi daerah sekarang ini, daerah diberikan kewenangan yang lebih besar untuk mengatur dan mengurus rumah tangganya sendiri titik tujuannya adalah mendekatkan pelayanan pemerintah kepada masyarakat memudahkan masyarakat untuk memantau dan mengontrol penggunaan dana yang bersumber dari anggaran pendapatan belanja daerah selain untuk menciptakan persaingan sehat antar daerah dan mendorong timbulnya inovasi. Sejalan dengan kewenangan tersebut pemerintah daerah diharapkan lebih mampu menggali sumber-sumber keuangan, khususnya untuk memenuhi kebutuhan pembiayaan pemerintahan dan pembangunan di daerahnya, melalui Pendapatan asli daerah tuntutan peningkatan pad semakin besar seiring dengan semakin banyaknya kewenangan pemerintah yang dilimpahkan kepala daerah disertai pengalihan personal peralatan, pembiayaan, dan dokumentasi dalam kurung P3D ke daerah dalam jumlah besar. Sumber-sumber penerimaan daerah yang potensial harus digali secara maksimal akan tetapi dalam koridor peraturan perundang-undangan yang berlaku. Kebijakan otonomi daerah merupakan langkah strategi dalam dua hal. Pertama, otonomi daerah merupakan jawaban terhadap permasalahan lokal bangsa Indonesia berupa ancaman disintegrasi bangsa kemiskinan, ketidakmerataan pembangunan, rendahnya kualitas hidup masyarakat dan masalah pembangunan sumber daya manusia. Kedua, otonomi daerah dan desentralisasi merupakan langkah strategi bangsa Indonesia untuk menyongsong era global ekonomi dengan memperkuat basis perekonomian daerah. ${ }^{13}$

Sejalan dengan perkembangan kebutuhan pengelolaan keuangan negara fungsi perbendaharaan dalam rangka pengelolaan sumber daya keuangan

${ }^{13}$ Mardiasmo, Analisis Laporan Kenangan Daerah, Yogyakarta, YKPN, hlm. 59. 
pemerintah yang terbatas secara efisien semakin penting fungsi pembendaharaan tersebut meliputi perencanaan kas yang baik, pencegahan terjadinya bocor dan penyimpangan, pencarian sumber pembiayaan yang paling murah, dan pemanfaatan dana yang menganggur untuk meningkatkan nilai tambah sumber daya keuangan.

Dalam pengelolaan keuangan negara/daerah dalam undang-undang ditegaskan kewenangan Menteri Keuangan untuk mengatur dan menyelenggarakan rekening pemerintah menyimpan uang negara dalam rekening kas umum negara Bank Sentral, serta ketentuan yang mengharuskan dilakukannya tim alisasi pemanfaatan dana pemerintah untuk meningkatkan transparansi dan dan akuntabilitas an-na'aam piutang negara/daerah titik Sementara itu, dalam pelaksanaan pembiayaan ditetapkan pejabat yang Diberi Kuasa untuk mengadakan utang negara atau daerah titik demikian pula, untuk meningkatkan efektivitas dan efisien pengelolaan investasi dan barang milik negara atau daerah pemerintah menetapkan ketentuan yang berkaitan dengan pelaksanaan investasi serta kewenangan mengelola dan menggunakan barang milik daerah atau negara.

Pemerintahan desa Berkaitan dengan pola wewenang yang berkembang di desa. Penguatan wewenang tersebut sejalan dengan peningkatan kekuasaan camat di wilayahnya. Sumber daya untuk menguatkan wewenang tersebut berupa pemberian dana bantuan desa secara rutin dan peningkatan proyek-proyek pembangunan desa seluruh dana dan pembangunan tersebut hanya dikelola oleh Pemerintah desa. Peningkatan sumber daya dari luar desa tersebut telah meningkatkan proporsi pihak luar dalam pendapatan desa peningkatan sumberdaya bagi pemerintah desa juga menurunkan kemampuan tokoh masyarakat untuk mengontrol pelaksanaan proyek pembangunan titik Hal tersebut mengarahkan pemerintah desa bersifat otokratik dan menurunkan derajat demokratisasi di desa. ${ }^{14}$

Tantangan dari pendekatan top-down terhadap desa-desa di Indonesia ialah meningkatkan kepuasan atau pemenuhan kebutuhan dasar sesuai dengan makna yang dikembangkan oleh masyarakat bukan oleh desa. Hasil kajian sebelumnya menginformasikan peranan pelayanan pabrik masyarakat desa, kesejahteraan warga, dengan kepuasan masyarakat. Kepuasan masyarakat menjadi indikator penting dalam menilai pelayanan yang diselenggarakan oleh pemerintah. Pemerintah perlu memiliki empati terhadap kebutuhan masyarakat. tujuan umum administrasi publik ialah meningkatkan tanggung jawab terhadap warga negara, meningkatkan wewenang publik untuk turut dalam keputusan atas kebijakan dan meningkatkan manfaat bagi warga negara titik dalam Undang-

${ }_{14}$ Effendy, K, Pergeseran Kepemimpinan Desa: Kharismatik, Paternalistik, Otokratik, Demokratik, Bandung, Indra Prahasta, 2012, hlm. 78. 
Undang Nomor 6 Tahun 2014 tanggung jawab kepada warga negara ditunjukkan oleh pelayanan pabrik yang diberikan pemerintah. Peningkatan wewenang pabrik yang mengambil keputusan ditunjukkan dalam partisipasi pada masyarakat pembangunan dan peningkatan manfaat kebijakan bagi masyarakat ditunjukkan oleh peningkatan kesejahteraan masyarakat.

Undang-Undang Desa memiliki peluang yang berbeda tergantung pada hasil musyawarah desa jika hasilnya mendukung pelayanan publik, maka akan meningkatkan kepuasan masyarakat. Jika hasilnya tidak mendukung pelayanan publik, maka kepuasan masyarakat menurun. Kepuasan masyarakat terhadap aparat pemerintah desa di Indonesia tergolong tinggi titik masyarakat juga memiliki perspektif positif terhadap pelayanan desa titik pelayanan tersebut dinilai sebagai indikator kinerja pemerintahan desa sekaligus peningkatan akses kebutuhan dasar titik pelayanan pemerintah desa dinilai meningkat sementara korupsi dinilai menurun. Tambahan dana desa yang diterjemahkan sebagai upaya pemerintah desa dapat meningkatkan kepuasan masyarakat.

Penempatan desa sebagai subsistem pemerintah kabupaten bisa dikatakan merupakan bentuk kekurangan berpihakan pemerintah kepala desa titik besar yang dimiliki Pemerintah Kabupaten daerah otonomi daerah diatur menjadi bumerang bagi desa pemerintah dan pemerintah daerah dan mempunyai komitmen kuat dan konsisten tinggi dalam memperhatikan desa. Sebaliknya, dengan kewenangannya pemerintah Kabupaten kurang memberikan kesempatan bagi desa untuk mandiri atau otonomi. Bahwa perhatian pemerintah maupun pemerintah daerah terhadap penyelenggaraan pemerintah dan pembangunan desa masykura pemerintah daerah tidak serius dalam memberikan pengakuan atau rekognisi dan perlindungan atau proteksi terhadap aspek-aspek kemasyarakatan desa. Komitmen pemerintah dan pemerintah daerah untuk memajukan desa serta meningkatkan kemandirian Desa belum terlihat konkret. Pemerintahan supra desa belum maksimal berbagi sumber daya dengan pemerintahan desa titik pemerintah daerah tidak memiliki terobosan program atau kebijakan dan aksi nyata dalam rangka memajukan desa. Demikian halnya kebijakan desentralisasi fiskal di desa, kebijakan anggaran pemerintah tampaknya juga belum memperlihatkan keberpihakan kepada desa. Program pemerintah tingkat atas yang diwujudkan dalam APBD atau APBN baik kuantitas maupun kualitas dipandang belum mampu memberikan kontribusi besar bagi pembangunan desa titik akselerasi pembangunan pedesaan tidak akan berjalan 
jika perhatian pemerintah tingkat atas, dalam bentuk kebijakan anggaran atau kebijakan regulasi yang lain belum menunjukkan keseriusan. ${ }^{15}$

Dari perspektif desa selama ini telah terjadi ketidakadilan anggaran antara desa dengan supra desa terbatasnya dana untuk desa selain disebabkan kebijakan umum atau regulasi yang kurang memperhatikan kepentingan desa atau prodesa juga akibat keterbatasan anggaran yang dimiliki pemerintah daerah dapat dicermati dalam struktur anggaran pemerintahan kabupaten/kota yang kurang proporsional. Pengeluaran belanja daerah kabupaten atau kota biasanya mayoritas digunakan untuk pembiayaan belanja tidak langsung TV dari bagian belanja langsung, belanja modal yang digunakan antara lain untuk pembangunan kecil. Sehingga struktur belanja daerah sebagian besar masih digunakan untuk belanja administrasi umum sedangkan bagian belanja modal sangat terbatas hal ini menunjukkan bahwa anggaran belanja pemerintah kabupaten/kota belum memperhatikan keberpihakan pada peningkatan kemampuan pemerintah daerah dalam meningkatkan kesejahteraan masyarakat.

Model pembangunan lembaga di atas cukup untuk menggambarkan persoalan yang dihadapi desa saat ini. dorongan perubahan di desa dapat dipetakan dari 5 variabel lembaga dan empat variabel kaitan tersebut Namun demikian dalam konteks penyelenggaraan pemerintahan desa ada satu variabel atau aspek yang bisa ditambahkan dan menjadi Payung dari modal pembangunan lembaga, yakni aspek politik. Dari aspek politik akan menghasilkan produk yang berupa regulasi atau peraturan perundang-undangan titik persoalan regulasi ini penting bagi desa, karena pemerintahan desa menjadi bagian dari struktur atau organisasi formal kenegaraan. Intervensi atas Peraturan perundang-undangan akan memberikan pengaruh signifikan bagi desa sebagai contoh regulasi atas penguatan kedudukan desa dapat berdampak pada tangan, keuangan, dan sumberdaya yang lain kualitas program termasuk kemandirian desa.

Pendirian politik desa antara lain dapat dilihat dari proses rekrutmen / pembinaan aparatur, pertanggungjawaban aparatur, perwujutan hak-hak politik/partisipasi masyarakat, dalam pembuatan kebijakan kebebasan dalam mengekspresikan hak asal usul desa dan adat istiadat titik kemandirian politik di desa sangat dipengaruhi karakteristik pemerintah desa dan BPD dari sisi kuantitas maupun kualitas, realitas kondisi aparatur pemerintah terbatas struktur Pemerintah desa yang lemah secara kuantitas maupun kualitas menjadi hambatan pelayanan bagi masyarakat dan peningkatan kinerja organisasi. misalnya dalam menyelenggarakan sosialisasi operasional PBB dan urusan

15 Nain, Umar, Relasi Pemerintahan Desa dan Supradesa Dalam Perencanaan dan Penganggaran Desa, Pustakapelajar, Yogyakarta, 2017, hlm. 280-281. 
administrasi Pemerintah desa terbengkalai, termasuk keterlambatan penyusunan anggaran pendapatan belanja desa titik semakin tidak mampu pemerintah desa menyelesaikan tugasnya, maka dorongan terhadap keberhasilan kemandirian desa semakin melemah titik pemerintahan desa juga akan cenderung semakin tergantung pada pemerintah tingkat atasnya.

Terkait dengan kebebasan dalam mengekspresikan hak asal usul desa dan adat istiadat, sumbernya regulasi atau undang-undang peraturan pemerintah peraturan daerah sudah membuka lebar kesempatan untuk mempertahankan dan melestarikan hak asal usul desa dan adat istiadat di desa titik batas desa dalam undang-undang juga menyebutkan bahwa desa merupakan satuan organisasi pemerintahan terendah dengan hak otonom yang berbasis asal-usul dan adat istiadat titik bahkan peraturan pemerintah Nomor 76/2001 menegaskan bahwa pemerintah daerah harus mengakui dan menghormati adat istiadat dan lembaga adat di wilayahnya. Pemerintah daerah dapat menetapkan berbagai kebijakan dalam upaya pemberdayaan, kelestarian dan pengembangan adat istiadat dan lembaga adat di wilayahnya implementasi atas aturan tersebut tidak efektif terutama karena hak asal usul desa dan adat istiadat di desa pada kenyataannya relatif sudah melalui.

Dari sudut kemandirian administrasi dari ekonomi, selama ini terdapat kecenderungan meningkatnya kemandirian masyarakat di satu sisi, dan stagnasi/kemunduran kemandirian Pemerintah desa di sisi lain, kemandirian masyarakat tersebut dipengaruhi oleh potensi masyarakat. Sedangkan potensi masyarakat banyak ditentukan oleh kondisi sosial ekonomi masyarakat. Dari sudut kemandirian politik, perubahan yang terjadi sangat terkait dan banyak dipengaruhi oleh desain peraturan perundang-undangan yang berlaku titik Selain desain peraturan perundang-undangan, potensi lokal juga mempunyai kontribusi terhadap kemandirian politik desa. Faktor-faktor pengaruh tersebut pada intinya bermuara pada adanya peluang dan bagaimana peluang itu dimanfaatkan bagi kemandirian desa. Selain melibatkan aksi reaksi antar sisi agency dan struktur terdapat satu variabel yang menentukan untuk membangun kemandirian desa, yaitu variabel Supra desa atau pemerintah tingkat atas. Faktor pengaruh yang bersifat eksternal tersebut bisa dipengaruhi oleh variabel supra desa. Faktor supra desa dapat menghasilkan produk hukum regulasi, kebijakankebijakan, dan sumber daya yang semuanya potensial untuk mempengaruhi kemandirian desa titik sehingga, agar kemandirian desa dapat diwujudkan maka faktor-faktor tersebut perlu diperhatikan dan diintervensi oleh pihak-pihak terkait. 
Pertanggungjawaban penyelenggaraan pemerintah desa merupakan suatu ukuran yang menunjukkan seberapa besar tingkat kesesuaian penyelenggaraan pelayanan dengan ukuran nilai nilai atau norma eksternal yang ada di masyarakat atau dimiliki oleh para pengguna (stakeholder). Secara umum pertanggungjawaban penyelenggaraan pelayanan publik seringkali masih merata standar nilai/norma pelayanan secara sepihak dari pemberian pelayanan yang harus berdasarkan juklak, sehingga cenderung terjadi pada melemahnya komitmen para birokrasi untuk dapat dipertanggungjawabkan titik rendahnya tingkat akuntabilitas Pemerintah desa dalam pelayanan masyarakat lebih cenderung disebabkan adanya prinsip loyal kepada atasan dibanding kepada publik titik dalam konteks akutan bilitas penyelenggaraan pemerintahan pembangunan dan kemasyarakatan, kepala desa mempunyai kewajiban untuk membuat dan menyampaikan laporan hasil penyelenggaraan pemerintahan desa pada setiap akhir tahun anggaran maupun di akhir masa jabatan termasuk didalamnya laporan pertanggungjawaban pelaksanaan keuangan desa

Berdasarkan uraian tersebut maka dapat kita pahami pentingnya laporan pertanggungjawaban Pemerintah desa sebagai bentuk akuntabilitas yaitu asas yang harus dipatuhi dalam penyelenggaraan pemerintah desa yang menentukan bahwa setiap kegiatan dan hasil akhir kegiatan penyelenggaraan pemerintahan desa harus dapat dipertanggungjawabkan kepada masyarakat desa sesuai dengan ketentuan peraturan perundang-undangan titik dalam konteks ini diharapkan dapat terbentuk pemerintahan desa yang profesional efisien dan efektif terbuka serta bertanggung jawab demi mewujudkan masyarakat desa yang maju sejahtera Mandiri dan bermartabat.

Sejalan dengan prinsip transparansi, akuntabel, dan partisipatif yang merupakan ciri dasar tata kelola pemerintah (goodgovernance), maka pertanggungjawaban tidak hanya disampaikan kepada pemerintah yang berwenang, tetapi juga harus disampaikan kepada masyarakat baik langsung maupun tidak langsung. Secara langsung, pertanggungjawaban kepada masyarakat bisa disampaikan melalui musyawarah desa sebagai forum untuk membahas hal-hal strategis, yang dihadiri BPD dan unsur-unsur masyarakat lainnya selain itu laporan pertanggungjawaban juga dapat disebarluaskan melalui berbagai cara komunikasi dan informasi: papan informasi desa, website resmi Pemerintah Kabupaten atau bahkan desa.

Ditegaskan dalam asas pengelolaan keuangan adanya asas partisipatif. Hal ini berarti dalam pengelolaan keuangan desa harus dibuka ruang yang luas sebagai peran aktif masyarakat titik sejauh yang ditetapkan dalam Permendagri laporan realisasi dan laporan pertanggungjawaban realisasi pelaksanaan 
APBDesa diinformasikan secara tertulis kepada masyarakat dengan menggunakan media yang mudah diakses oleh masyarakat. Maksud pokok dari penginformasian itu adalah agar seluas mungkin masyarakat yang mengetahui berbagai hal terkait dengan kebijakan dan Realisasi pelaksanaan anggaran pendapatan belanja desa. Dengan demikian masyarakat dapat memberikan masukan saran, koreksi, terhadap pemerintah desa, baik yang berkenaan dengan anggaran pendapatan belanja desa yang telah maupun yang akan dilaksanakan.

Untuk pemberian sanksi di dalam Pasal 28 Undang-Undang Nomor 6 Tahun 2004 tentang Desa, disebutkan bahwa kepala desa yang tidak melaksanakan kewajiban dikenai sanksi administratif berupa teguran lisan dan atau teguran tertulis titik dalam hal sanksi administratif tidak dilaksanakan dilakukan tindakan pemberhentian sementara dan dapat dilanjutkan dengan pemberhentian. Berdasarkan peraturan Menteri Dalam Negeri Nomor 60 Tahun 2014 tentang dana desa yang bersumber dari anggaran pendapatan dan belanja negara Pasal 25 dalam hal kepala desa tidak atau terlambat menyampaikan laporan realisasi penggunaan dana desa, bupati/walikota dapat menunda Penyaluran dana desa sampai dengan disampaikannya laporan realisasi penggunaan dana desa. Dalam Pasal 27 Peraturan Pemerintah Nomor 22 Tahun 2014 tentang perubahan atas Peraturan Pemerintah No. 60 Tahun 2014 tentang dana desa yang bersumber dari anggaran pendapatan Belanja Negara titik disebutkan bahwa terdapat Silpa dana desa lebih dari 30\% pada akhir tahun anggaran sebelumnya, bupati/walikota memberikan sanksi administratif kepala desa yang bersangkutan titik sanksi berupa penundaan Penyaluran dana desa tahap 1 Tahun Anggaran berjalan Sebesar Silpa Dana Desa titik dalam hal Tahun Anggaran berjalan masuk terdapat silpa dana desa lebih dari 30\%, Bupati garing Walikota memberikan sanksi administratif Kepada Desa yang bersangkutan titik sanksi berupa pemotongan Dana Desa Tahun Anggaran berikutnya sebesar Silpa Dana Desa tahun berjalan titik pemotongan Penyaluran dana desa menjadi dasar menteri melakukan pemotongan Penyaluran dana desa untuk kabupaten/kota tahun anggaran berikutnya ketentuan mengenai pengenaan sanksi administratif diatur dengan peraturan Bupati / Walikota.

\section{Penutup}

Kebijakan alternatif undang-undang nomor 6 Tahun 2014 tentang desa mengenai masalah pemerintahan desa mendapatkan pengaruh dari lingkungan berupa peraturan dan kebijakan sumber daya dan teknologi lokal. Masukan untuk pelaksanaan pemerintahan desa berupa program pembangunan dan 
pendanaan titik proses pelayanan urusan pemerintah di tingkat desa dilaksanakan oleh aparatur Pemerintah desa dan lembaga lokal atau dengan pendampingan dari pihak luar desa tersebut dilaksanakan menurut norma yang dikenalkan dalam Undang-Undang Nomor 6 Tahun 2014 tentang Desa. Hasil yang diharapkan jasa dan kawasan yang jelas hasil sarana dan prasarana pemenuhan kebutuhan primer atau dasar, hasil hasil usaha ekonomi aliran dana bantuan sosial dan hibah untuk orang miskin, pelayanan pemerintahan desa, berbagai kegiatan masyarakat yang meningkatkan pengetahuan sikap dan keterampilan masyarakat titik yang bisa diambil dari hasil tersebut berupa peningkatan efektivitas Pemerintah desa untuk mempercepat dan meningkatkan akses maupun kualitas pelayanan pemerintahan desa kepada masyarakat dan percepatan pembangunan pemberdayaan masyarakat, pembinaan kelembagaan masyarakat serta kestabilan keamanan dan ketertiban. Manfaat yang berkelanjutan yang berupa peningkatan kualitas hidup, kehidupan dan kesejahteraan masyarakat, serta pengurangan kemiskinan, juga tercapainya kemandirian, pendapatan desa dan daya saing desa. Bahwa kebijakan afirmatif Undang-Undang Nomor 6 Tahun 2014 tentang desa berpengaruh positif terhadap efektivitas pemerintahan desa. Hal ini ditunjukkan oleh peningkatan efektivitas organisasi pemerintah Desa efektivitas deliberasi musyawarah desa.

Tingkat kemandirian administratif/ekonomi desa yang pertama diamati oleh proporsi Pendapatan asli desa dibanding dengan pendapatan Desa secara keseluruhan titik kontribusi pendapatan asli desa terhadap seluruh pendapatan Desa pada umumnya masih minim dan terbatas. Sumber pendapatan desa sejak dahulu hingga sekarang relatif tidak memberikan pendapatan bagi desa secara signifikan. Ketidakmampuan untuk meningkatkan pendapatan desa tersebut dikarenakan potensi komponen sumber pendapatan desa relatif kurus atau dengan kata lain tidak memberikan hasil optimal. Sedangkan kemandirian politik di desa sangat dipengaruhi karakteristik pemerintah desa dan BPD dari sisi kuantitas maupun kualitas realitas kondisi aparatur Pemerintah amat terbatas struktur pemerintah desa yang lemah secara kuantitas maupun kualitas menjadi hambatan pelayanan bagi warga masyarakat dan peningkatan kinerja organisasi. Semakin tidak mampu pemerintah desa menyelesaikan tugasnya maka dorongan terhadap keberhasilan kemarin desa semakin melemah titik pemerintah desa juga akan cenderung semakin tergantung kepada pemerintah tingkat atasannya. Untuk memperkuat kemandirian desa hendaknya kemandirian ekonomi mendapatkan perhatian. Dalam hal kemandirian ekonomi upaya penguatan kapasitas pembiayaan desa terlihat dari semakin diperluasnya akses terhadap sumber daya pendanaan. Peluang memberdayakan desa bisa lebih dimungkinkan 
melalui pemberdayaan badan usaha milik desa dan kerjasama desa dengan desa lain dan atau kerjasama dengan pihak ketiga.

\section{Daftar Pustaka}

\section{Buku}

Conyers, Perencanaan Sosial Di Dunia Ketiga Suatu Pengantar, Gadjah Mada University Pers, Yogyakarta, 1991.

Fadli, Moh., Jazim Hamidi, Mustafa Lutfi, Pembentukan Peraturan Desa Partisipatif (Head to A Good Village Governance).

Ihsan, M. Mustofa., Ketahanan Masyarakat Desa, Kementerian Desa Pembangunan Daerah Tertinggal dan Transmigrasi Republik Indonesia, Jakarta, 2015.

K, Effendy, Pergeseran Kepemimpinan Desa: Kharismatik, Paternalistik, Otokratik, Demokratik, Indra Prahasta, Bandung, 2012.

Mardiasmo, Analisis Laporan Keuangan Daerah, Yogyakarta, YKPN.

Nain, Umar, Relasi Pemerintah Desa Dan Supradesa Dalam Perencanaan dan Penggaran Desa, Pustaka Pelajar, Yogyakarta, 2017.

Martosoewignjo, Sri Soemantri, Sistem-Sistem Pemerintahan Negara-Negara ASEAN, Tarsito, Bandung, 1976.

Riyadi dan Bratakusumah, Perencanaan Pembangunan Daerah, Gramedia Pustaka Utama, Jakarta, 2004.

Soleh, Chabib, dan Heru Rochmansjah, Pengelolaan Keuangan Desa, Fokus Media, Bandung, 2014.

Widjaja, HAW., Otonomi Desa, Raja Grafindo Indonesia, Jakarta, 2012.

\section{Lain-lain}

Undang-undang Nomor 6 Tahun 2014 tentang Desa.

Peraturan Dalam Negeri Nomor 20 tahun 2018 tentang Pengelolaan Keuangan Desa. 